Jurnal Ilmu Ilmu Agribisnis: Journal of Agribusiness Science, 9(2), Mei 2021

\title{
HUBUNGAN MOTIVASI, KEMAMPUAN, KEDISIPLINAN, DAN KEPUASAN KERJA DENGAN KINERJA MANDOR DI PT GREAT GIANT PINEAPPLE DEPARTEMEN PG 2 LAMPUNG TENGAH
}

\author{
(The Relationship of Motivation, Ability, Discipline, and Job Satisfaction with Their Performance at PT \\ Great Giant Pineapple Department PG 2 in Center Lampung Regency)
}

Arnum Wahida Banati Husna, Wuryaningsih Dwi Sayekti, Adia Nugraha

Jurusan Agribisnis, Fakultas Pertanian, Universitas Lampung, Jl. Prof. Dr. Soemantri Brodjonegoro No. 1

Bandar Lampung 35145, e-mail : wuryaningsih.dwisayekti@fp.unila.ac.id

\begin{abstract}
The purposes of this study are to find out the level of motivation, ability, discipline, and job satisfaction, and their relationship with the performance of the foremen at PT Great Giant Pineapple Department of PG 2. This research uses a census method with 67 foremen and 19 section heads as respondents. Data collection was conducted in August to October 2019. Primary data in this study are motivation, ability, discipline, and job satisfaction, while secondary data used are foreman performance. The data are analyzed using Pearson Product Moment correlation analysis method. The results showed that motivation, discipline, and job satisfaction of the foremen are in the very high category, while the foreman's ability is in the high category. Motivation, ability, and discipline have a positive and significant relationship with the performance of the foremen, whereas job satisfaction does not relate to the performance of the foremen.
\end{abstract}

Key words: ability, discipline, job satisfaction, motivation

\section{PENDAHULUAN}

Pertumbuhan ekonomi Provinsi Lampung sangat didukung oleh sektor pertanian. Berdasarkan data Produk Domestik Regional Bruto (PDRB) berdasarkan lapangan usaha, sektor pertanian adalah penyumbang terbesar yaitu 31,92 persen pada tahun 2015 , 31,68 persen pada tahun 2016, 30,40 persen pada tahun 2017, dan 30,00 persen pada tahun 2018 (Badan Pusat Statistik 2019). Sumbangann sektor pertanian terhadap pertumbuhan ekonomi selalu yang tertinggi, meskipun mengalami penurunan setiap tahunnya.

Peran sektor industri pengolahan dalam pertumbuhan ekonomi Provinsi Lampung adalah tertinggi kedua setelah sektor pertanian, yaitu sebesar 19,05 persen pada tahun 2015, 18,64 persen pada tahun 2016, 18,91 persen pada tahun 2017, dan 19,44 persen pada tahun 2018 (Badan Pusat Statistik 2019). Hasil dari kegiatan di sektor pertanian biasanya hanya dipasarkan tanpa diolah, sedangkan apabila hasil tersebut diolah terlebih dahulu akan bernilai jual lebih tinggi yang kemudian dapat meningkatkan pertumbuhan ekonomi Provinsi Lampung.

Salah satu perusahaan dari sektor industri pengolahan di Provinsi Lampung adalah PT Great Giant Pineapple. PT Great Giant Pineapple merupakan perusahaan yang bergerak di bidang pertanian dengan menerapkan konsep agribisnis dalam kegiatan usahanya, dimulai dari kegiatan budidaya nanas, pengolahan hasil produksi, hingga pemasaran. Hal tersebut berbanding lurus dengan banyaknya sumberdaya manusia yang dibutuhkan oleh PT Great Giant Pineapple dalam melakukan kegiatan operasionalnya. Jumlah tenaga kerja di pabrik dan perkebunan PT Great Giant Pineapple mencapai kurang lebih 20.000 orang pekerja (PT Great Giant Pineapple 2018).

Sumberdaya manusia atau karyawan adalah salah satu bagian penting perusahaan yang perlu dikelola dengan baik dan benar, karena setiap kegiatan usaha dalam sebuah perusahaan akan dijalankan oleh karyawan yang dimiliki. Hasil dari pekerjaan tersebut akan dinilai. Penilaian kinerja dapat digunakan sebagai bahan untuk memperbaiki kualitas pekerjaan dan mengetahui kebutuhan akan pelatihan dan pengembangan karyawan.

Pada PT Great Giant Pineapple kinerja seorang karyawan dinilai secara kualitatif dan kuantitatif. Penilaian kinerja secara kualitatif dilihat dari sikap dan perilaku kerja karyawan yang dilihat berdasarkan beberapa indikator, yaitu kemampuan karyawan dalam berfikir jernih, bekerja sama dengan rekan kerja, kreatifitas dalam bekerja, keahlian karyawan, dan fokus terhadap pelanggan. Kemudian penilaian kinerja secara kuantitatif 
dilihat dari kemampuan karyawan dalam mengerjakan dan menyelesaikan tugasnya.

Hasil kinerja mandor dinilai berdasarkan pencapaian mandor atas pekerjaannya yang dinilai oleh atasan berdasarkan indikator yang diterapkan oleh perusahaan kemudian dirata-rata per-periode (satu tahun). Terdapat penurunan kinerja mandor baik kinerja kualitatif maupun kinerja kuantitatif dari tahun 2016 sampai 2017. Kinerja kualitatif mengalami penurunan sebesar 8,80 persen, yaitu dari 89,70 persen menjadi 80,90 persen. Kemudian kinerja kuantitatif mengalami penurunan sebesar 3,50 persen, yaitu dari 97,80 persen menjadi 94,30 persen (PT Great Giant Pineapple 2018). Akibat dari penurunan kinerja mandor ini dapat berpengaruh terhadap kemampuan perusahaan dalam mencapai tujuan.

Kinerja karyawan menurut Mangkunegara (2005) adalah hasil kerja secara kualitas dan kuantitas yang telah dicapai oleh karyawan sesuai dengan tugas dan tanggung jawab yang dijalankannya. Kinerja karyawan dari pelaksanaan pekerjaannya dapat dipengaruhi oleh beberapa hal. Seorang pemimpin sebaiknya mengetahui dan memahami faktor-faktor yang dapat memengaruhi kinerja karyawannya. Beberapa faktor yang dapat memengaruhi kinerja para karyawan menurut Kasmir (2016) adalah kemampuan dan keahlian, pengetahuan, rancangan kerja, kepribadian, motivasi kerja, kepemimpinan, gaya kepemimpinan, budaya organisasi, kepuasan kerja, lingkungan kerja, loyalitas, komitmen, dan disiplin kerja.

Berdasarkan penelitian pendahuluan yang telah dilakukan kepada mandor dan kepala seksi terdapat masalah pada motivasi, kemampuan, kedisiplinan, dan kepuasan kerja. Permasalahan tersebut diduga memiliki hubungan dengan penurunan kinerja mandor. Oleh karena itu perlu dilakukan penelitian ini dengan tujuan untuk mengetahui tingkat motivasi, kemampuan, kedisiplinan, dan kepuasan kerja mandor pada PT Great Giant Pineapple Departemen PG 2 Lampung Tengah, serta mengetahui hubungan motivasi, kemampuan, kedisiplinan, dan kepuasan kerja dengan kinerja mandor pada PT Great Giant Pineapple Departemen PG 2 Lampung Tengah.

\section{METODE PENELITIAN}

Metode yang digunakan pada penelitian ini adalah metode sensus dengan jumlah populasi mandor sebanyak 67 orang. Pemilihan metode ini didasari oleh teori Arikunto (2012) yang menyatakan jika jumlah populasi kurang dari 100 orang, maka jumlah sampelnya diambil secara keseluruhan. Responden pada penelitian berjumlah 86 orang, yang terdiri atas 67 orang mandor dan 19 orang kepala seksi. Lokasi penelitian adalah di PT Great Giant Pineapple Departemen PG 2 Lampung Tengah. Pemilihan lokasi dilakukan secara sengaja (purposive) dengan pertimbangan bahwa PT Great Giant Pineapple merupakan salah satu perusahaan agribisnis yang cukup besar di Lampung dan terdapat masalah penurunan kinerja mandor pada Departemen PG 2. Pengumpulan data dilaksanakan pada Bulan Agustus sampai dengan Oktober 2019.

Data yang digunakan dalam penelitian ini adalah data primer dan data sekunder. Data primer adalah data yang diperoleh langsung oleh peneliti dari responden, yang pada penelitian ini merupakan mandor dan kepala seksi pada PT Great Giant Pineapple Departemen PG 2 Lampung Tengah. Metode pengumpulan data primer pada penelitian ini diperoleh menggunakan kuesioner (daftar pernyataan) tertutup tentang motivasi, kemampuan, kedisiplinan, dan kepuasan kerja mandor dengan menggunakan skala likert sebagai pilihan jawaban, sehingga memerlukan adanya uji validitas dan reliabilitas. Uji validitas dan reliabilitas ini dilakukan untuk menguji apakah pernyataanpernyataan di kuesioner sudah valid dan reliabel untuk mengukur variabel-variabel dalam penelitian.

Variabel motivasi dalam penelitian ini dinilai berdasarkan 3 indikator, yaitu achievement motivation yang akan dilihat dari bagaimana keinginan mandor dalam mencapai target (X1.1), upaya mengatasi risiko kegagalan dari pekerjaan (X1.2), dan tingkat harapan mandor atas umpan balik dari kinerjanya (X1.3), affiliation motivation yang akan dilihat dari hubungan antar rekan kerja (X1.4), kecocokan dengan rekan kerja (X1.5), dan sikap rekan kerja dalam bekerja sama (X1.6), dan power motivation yang akan dilihat dari keinginan untuk memimpin (X1.7) dan memiliki kekuasaan (X1.8). Variabel kemampuan dinilai berdasarkan 3 indikator, yaitu keterampilan akan dilihat dari kemampuan mandor dalam menyelesaikan tugas (X2.2 dan X2.4), kecakapan mandor dalam bekerja (X2.3 dan X2.5), dan menghadapi serta menyelesaikan masalah (X2.6), pengetahuan yang akan dilihat dari latar belakang pendidikan (X2.1) dan seberapa paham mandor akan pekerjaannya (X2.7), dan pengalaman kerja (X2.8 dan X2.9). Variabel kedisiplinan dinilai berdasarkan 3 
indikator, yaitu taat aturan waktu (X3.1, X3.2, dan $\mathrm{X} 3.3)$, taat aturan perusahaan (X3.4, X3.5, dan $\mathrm{X} 3.6)$, dan perilaku dalam bekerja (X3.7, X3.8, dan X3.9). Variabel kepuasan kerja dinilai berdasarkan 8 indikator, yaitu Pay Satisfaction (X4.1, X4.2, dan X4.3), Promotion Satisfacion (X4.4 dan X4.5), Supervision Satisfaction (X4.6 dan X4.7), Coworker Satisfaction (X4.8 dan $\mathrm{X} 4.9)$, Satisfaction with the Work itself (X4.10), Altruism (X4.11 dan X4.12), Status (X4.13), dan Environment (X4.14 dan X4.15). Masing-masing indikator dibuat satu sampai tiga butir pernyataan yang kemudian dilakukan uji validitas dan reliabilitas.

Uji validitas dianalisis pada semua variabel dengan menggunakan analisis korelasi rank spearman pada SPSS 23. Kriteria yang digunakan untuk menilai apakah variabel yang diuji valid adalah dengan membandingkan nilai $r$ hitung dengan nilai kritis sebesar 0,20. Apabila $r$ hitung > nilai kritis maka variabel tersebut valid, sedangkan bila $r$ hitung $<0,20$ maka variabel tersebut tidak valid. Hasil uji validitas dapat dilihat pada Tabel 1. Data pada Tabel 1 menunjukkan bahwa seluruh butir pernyataan dari variabel motivasi, kemampuan, kedisiplinan, dan kepuasan kerja memiliki nilai $r$ hitung lebih besar dari nilai kritis $(0,20)$. Hal tersebut menunjukkan bahwa seluruh pernyataan pada kuesioner adalah valid, sehingga dapat digunakan untuk mengambil data lanjutan.

Uji reliabilitas dianalisis pada semua variabel dengan menggunakan SPSS 23. Kriteria yang digunakan untuk menilai apakah variabel yang diuji reliabel adalah dengan membandingkan nilai Cronbach's Alpha dengan nilai kritis sebesar 0,60. Apabila Cronbach's Alpha $>0,60$ maka variabel tersebut reliabel, sedangkan bila Cronbach's Alpha $<0,60$ maka variabel tersebut tidak reliabel. Hasil uji reliabilitas dapat dilihat pada Tabel 2. Data pada Tabel 2 menunjukkan bahwa nilai Cronbach's Alpha variabel motivasi, kemampuan, kedisiplinan, dan kepuasan kerja lebih besar dari nilai kritis yaitu 0,60 artinya seluruh pernyataan dalam kuesioner dinyatakan reliabel. Hal ini berarti kuesioner tersebut dapat digunakan untuk mengambil data lanjutan.

Data sekunder merupakan data yang diperoleh melalui pihak lain atau melalui dokumen (elektronik maupun cetak). Data sekunder pada penelitian ini diperoleh dari studi literatur/laporan publikasi yang sesuai dengan penelitian dan Badan
Tabel 1. Hasil uji validitas

\begin{tabular}{rrrc}
\hline Pernyataan & r-hitung & Nilai Kritis & Keterangan \\
\hline X1.1 & 0,690 & 0,20 & Valid \\
X1.2 & 0,541 & 0,20 & Valid \\
X1.3 & 0,573 & 0,20 & Valid \\
X1.4 & 0,653 & 0,20 & Valid \\
X1.5 & 0,466 & 0,20 & Valid \\
X1.6 & 0,677 & 0,20 & Valid \\
X1.7 & 0,655 & 0,20 & Valid \\
X1.8 & 0,665 & 0,20 & Valid \\
X2.1 & 0,369 & 0,20 & Valid \\
X2.2 & 0,590 & 0,20 & Valid \\
X2.3 & 0,762 & 0,20 & Valid \\
X2.4 & 0,558 & 0,20 & Valid \\
X2.5 & 0,547 & 0,20 & Valid \\
X2.6 & 0,862 & 0,20 & Valid \\
X2.7 & 0,618 & 0,20 & Valid \\
X2.8 & 0,598 & 0,20 & Valid \\
X2.9 & 0,442 & 0,20 & Valid \\
X3.1 & 0,806 & 0,20 & Valid \\
X3.2 & 0,866 & 0,20 & Valid \\
X3.3 & 0,845 & 0,20 & Valid \\
X3.4 & 0,369 & 0,20 & Valid \\
X3.5 & 0,854 & 0,20 & Valid \\
X3.6 & 0,769 & 0,20 & Valid \\
X3.7 & 0,876 & 0,20 & Valid \\
X3.8 & 0,838 & 0,20 & Valid \\
X3.9 & 0,789 & 0,20 & Valid \\
X4.1 & 0,652 & 0,20 & Valid \\
X4.2 & 0,586 & 0,20 & Valid \\
X4.3 & 0,418 & 0,20 & Valid \\
X4.4 & 0,438 & 0,20 & Valid \\
X4.5 & 0,522 & 0,20 & Valid \\
X4.6 & 0,453 & 0,20 & Valid \\
X4.7 & 0,419 & 0,20 & Valid \\
X4.8 & 0,364 & 0,20 & Valid \\
X4.9 & 0,413 & 0,20 & Valid \\
X4.10 & 0,487 & 0,20 & Valid \\
X4.11 & 0,571 & 0,20 & Valid \\
X4.12 & 0,452 & 0,20 & Valid \\
X4.13 & 0,688 & 0,20 & Valid \\
X4.14 & 0,459 & 0,20 & Valid \\
X4.15 & 0,457 & 0,20 & Valid \\
\hline X & & &
\end{tabular}

Pusat Statistik (BPS) dan PT Great Giant Pineapple Lampung Tengah. Data sekunder yang diperoleh dari BPS berupa data Produk Domestik Regional Bruto (PDRB) Provinsi Lampung pada tahun 2019, sedangkan data sekunder yang berasal dari PT Great Giant Pineapple adalah data kinerja mandor pada tahun 2016 sampai 2017.

Metode analisis data yang digunakan dalam penelitian ini adalah analisis statistik deskriptif dan analisis statistik inferensial. Analisis statistik deskriptif digunakan untuk menjawab tujuan pertama, yaitu mengetahui tingkat motivasi, tingkat kemampuan, tingkat kedisiplinan, dan tingkat kepuasan kerja. Tingkat motivasi, kemampuan, kedisiplinan, dan kepuasan kerja mandor akan diklasifikasikan dalam kelas-kelas. 
Tabel 2. Hasil uji reliabilitas

\begin{tabular}{lccc}
\hline Pernyataan & Cronbach Alpha & nilai kritis & Ket \\
\hline Motivasi & 0,716 & 0,60 & Reliabel \\
Kemampuan & 0,748 & 0,60 & Reliabel \\
Kedisiplinan & 0,916 & 0,60 & Reliabel \\
Kepuasan & 0,774 & 0,60 & Reliabel \\
Kerja & & & \\
\hline
\end{tabular}

Analisis statistik inferensial digunakan untuk menguji hipotesis hubungan antara motivasi, kemampuan, kedisiplinan, dan kepuasan kerja dengan kinerja mandor, yang akan menjawab tujuan kedua. Teknik analisis statistik inferensial yang digunakan dalam penelitian ini adalah metode analisis korelasi Pearson Product Moment. Data primer yang diperoleh dari wawancara merupakan data ordinal, untuk menggunakan metode analisis korelasi Pearson Product Moment data ordinal perlu diubah dahulu menjadi data interval. Metode yang digunakan untuk mengubah data adalah Method of Successive Interval (MSI) dengan menggunakan program Microsoft Office Excel. Tingkat keeratan antar variabel dapat diinterpretasi dengan melihat nilai koefisien korelasi yang didapatkan dari hasil analisis korelasi Pearson Product Moment dengan ketentuan yang merujuk pada teori Guilford (1956) yang dapat dilihat pada Tabel 3.

Hubungan antar variabel yang diharapkan adalah hubungan yang positif dan signifikan. Untuk mengetahui apakah antar variabel memiliki hubungan yang signifikan dilakukan dengan melihat nilai signifikansi, dan kriterianya adalah:

1) Nilai signifikansi >0,05, artinya motivasi, kemampuan, kedisiplinan, dan kepuasan kerja tidak memiliki hubungan yang signifikan kinerja mandor.

2) Nilai signifikansi $<0,05$, artinya motivasi, kemampuan, kedisiplinan, dan kepuasan kerja memiliki hubungan yang signifikan dengan kinerja mandor.

\section{HASIL DAN PEMBAHASAN}

PT Great Giant Pinepple berlokasi di Jl. Lintas Timur Km 77 Kecamatan Terbanggi Besar Kabupaten Lampung Tengah. Pada lokasi ini terdapat areal perkebunan, pabrik pengolahan buah, dan unit operasional. Areal perkebunan pada PT Great Giant Pineapple dibagi menjadi empat bagian, yaitu Departemen Plantation Group atau PG 1, PG 2, PG 3, dan PG 4. PT Great Giant Pineapple memiliki luas areal kurang lebih 32.200 ha dengan luas efektif penanaman 25.595 ha.
Tabel 3. Interpretasi korelasi berdasarkan nilai koefisien korelasi

\begin{tabular}{lc}
\hline Nilai koefisien korelasi & Interpretasi \\
\hline $0,80-1,00$ & Sangat Tinggi \\
$0,60-0,80$ & Tinggi \\
$0,40-0,60$ & Cukup \\
$0,20-0,40$ & Rendah \\
$0,00-0,20$ & Sangat Rendah \\
\hline
\end{tabular}

\section{Karakteristik Responden}

Karakteristik responden adalah ciri yang mencerminkan keadaan dari tiap responden. Pada penelitian ini karakteristik responden dilihat dari umur, pendidikan terakhir, masa kerja, status pegawai, jumlah tanggungan dalam keluarga, dan status pegawai. Keseluruhan mandor berada pada kisaran umur 15 sampai 64 tahun dengan persentase sebesar 100 persen. Berdasarkan teori dari Mantra (2004) semua mandor pada Departemen PG 2 berada pada umur produktif secara ekonomi, yang artinya mandor cukup potensial untuk melakukan kegiatan produksi.

Sebagian besar pendidikan terakhir mandor adalah lulusan SMA/ sederajat dengan persentase sebesar 85,07 persen. Mandor dengan lulusan SMA/ sederajat memiliki jumlah paling banyak, karena sejak tahun 2000 PT Great Giant Pineapple menetapkan standar pendidikan untuk menjadi mandor adalah lulusan SMA / sederajat. Masa kerja mandor mayoritas berada pada kisaran 16 sampai 22 tahun yaitu sebesar 26,87 persen. Masa kerja mandor yang semakin lama akan memengaruhi kinerja mandor, karena mandor akan lebih memahami dan menguasai pekerjaan yang diampunya.

Jumlah anggota keluarga yang ditanggung oleh mandor mayoritas berkisar antara 2 sampai 3 orang dengan persentase sebesar 58,21 persen. Berdasarkan Norma Keluarga Kecil Bahagia Sejahtera (NKKBS) menurut BKKBN (2010) jumlah anggota keluarga sebanyak 2 sampai 3 orang masuk ke dalam kategori keluarga kecil karena kategori keluarga kecil adalah sebaiknya memiliki anak sebanyak 2 orang. Status pegawai sebagian besar mandor adalah kontrak yakni sebanyak 55,22 persen, sedangkan sisanya 44,78 persen mandor berstatus tetap. Posisi mandor dapat diisi oleh karyawan dengan status kontrak karena mandor dengan status kontrak memiliki ikatan masa kerja selama 2 tahun dengan perusahaan. 
Jurnal Ilmu Ilmu Agribisnis: Journal of Agribusiness Science, 9(2), Mei 2021

\section{Deskripsi Variabel}

Distribusi jawaban mandor pada indikator umpan balik atas kinerja lebih bervariasi dibandingkan indikator lainnya. Hal ini menunjukkan adanya perbedaan umpan balik yang diterima oleh masingmasing mandor. Total skor yang diperoleh pada variabel motivasi adalah sebesar 2.508 , kemudian dilakukan perhitungan untuk mengetahui rentang kategorisasi dan didapatkan hasil 429 dengan batas bawah 536 dan batas atas 2.680. Setelah itu dibuat garis kategorisasi seperti Gambar 1 dan variabel motivasi masuk ke dalam kategori sangat tinggi.

Jawaban mandor pada indikator pengalaman sebelum menjadi mandor dan pendidikan terakhir mandor lebih bervariasi dibandingkan indikator lainnya. Perbedaan tersebut dapat memengaruhi tingkat kemampuan para mandor. Total skor pada variabel kemampuan adalah sebesar 2.475, kemudian dilakukan perhitungan untuk mengetahui rentang kategorisasi dan didapatkan hasil 462 dengan batas bawah 603 dan batas atas 3.015. Setelah itu dibuat garis kategorisasi seperti Gambar 2 dan variabel kemampuan masuk ke dalam kategori tinggi.

Jawaban mandor pada indikator kehadiran mandor selama jam kerja lebih bervariasi dibandingkan indikator lainnya, hal ini menunjukkan adanya perbedaan kedisiplinan pada masing-masing mandor. Total skor pada variabel kemampuan adalah sebesar 2.683. Kemudian dibuat garis kategorisasi seperti Gambar 3 dengan rentang kategori sebesar 482, batas bawah 603 , dan batas atas sebesar 3.015 variabel kemampuan masuk ke dalam kategori sangat tinggi.

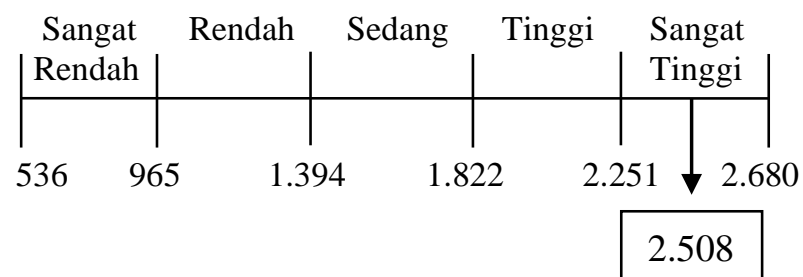

Gambar 1. Garis kategorisasi variabel motivasi

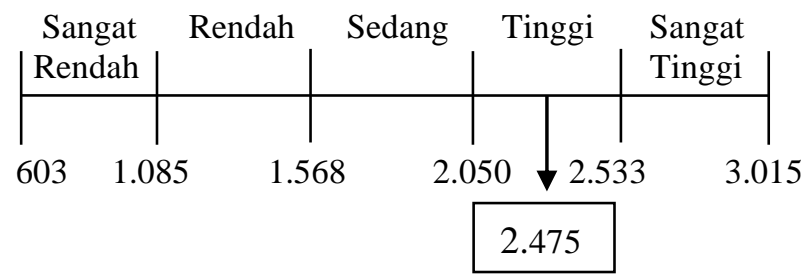

Gambar 2. Garis kategorisasi variabel kemampuan

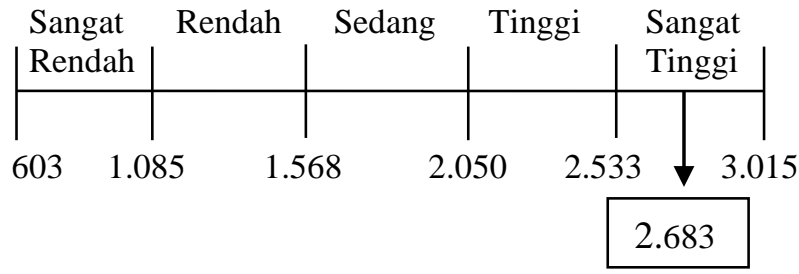

Gambar 3. Garis kategorisasi variabel kedisiplinan

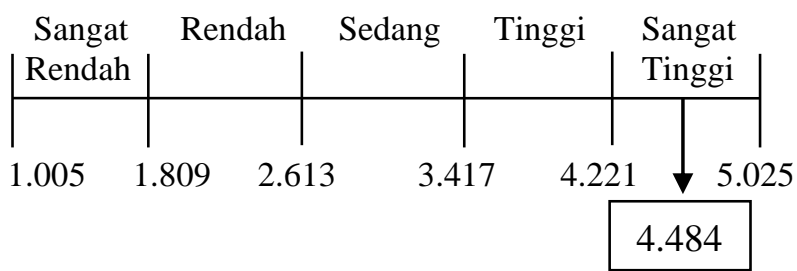

Gambar 4. Garis kategorisasi variabel kepuasan kerja

Jawaban mandor pada indikator pengetahuan mandor akan promosi, kesesuaian gaji dengan pekerjaan dan kebutuhan, sikap atasan dalam bekerja, dan penghargaan atas pencapaian target kerja lebih bervariasi dibandingkan indikator lainnya. Total skor pada variabel kemampuan adalah sebesar 4.484, setelah dibuat garis kategorisasi dengan rentang kategori sebesar 804 , batas bawah 1.005, dan batas atas 5.025 seperti Gambar 4. Variabel kemampuan masuk ke dalam kategori sangat tinggi.

\section{Analisis Korelasi Pearson Product Moment}

Untuk mengetahui variabel-variabel yang memiliki hubungan dengan kinerja mandor pada PT Great Giant Pineapple departemen PG 2 digunakan analisis korelasi pearson product moment. Hasil analisis korelasi pearson product moment dengan menggunakan program SPSS dapat dilihat pada Tabel 4.

Pada Tabel 4 nilai signifikansi variabel motivasi, kemampuan, dan kedisiplinan lebih kecil dari 0,05, maka variabel motivasi, kemampuan, dan kedisiplinan memiliki hubungan dengan variabel terikat yaitu kinerja. Akan tetapi variabel kepuasan kerja memiliki nilai signifikansi yang lebih besar dari 0,05, sehingga variabel kepuasan kerja tidak memiliki hubungan dengan kinerja. Penjelasan lebih lanjut mengenai hubungan antara variabel motivasi, kemampuan, kedisiplinan, dan kepuasan kerja dengan kinerja adalah sebagai berikut. 
Tabel 4. Hasil analisis korelasi pearson product moment

\begin{tabular}{|c|c|c|c|c|c|c|}
\hline & & Kinerja & Motivasi & Kemampuan & Kedisiplinan & Kepuasan Kerja \\
\hline & Pearson Correlation & 1 & $0,300^{*}$ & $0,392^{* *}$ & $0,322^{* *}$ & 0,121 \\
\hline \multirow[t]{3}{*}{ Kinerja } & Sig. (2-tailed) & & 0,014 & 0,001 & 0,008 & 0,328 \\
\hline & $\mathrm{N}$ & 67 & 67 & 67 & 67 & 67 \\
\hline & Pearson Correlation & $0,300^{*}$ & 1 & $0,339^{* *}$ & $0,349^{* *}$ & $0,593^{* *}$ \\
\hline \multirow[t]{3}{*}{ Motivasi } & Sig. (2-tailed) & 0,014 & & 0,005 & 0,004 & 0 \\
\hline & $\mathrm{N}$ & 67 & 67 & 67 & 67 & 67 \\
\hline & Pearson Correlation & $0,392^{\text {** }}$ & $0,339^{* * *}$ & 1 & $0,735^{* *}$ & $0,272^{*}$ \\
\hline \multirow[t]{3}{*}{ Kemampuan } & Sig. (2-tailed) & 0,001 & 0,005 & & 0 & 0,026 \\
\hline & $\mathrm{N}$ & 67 & 67 & 67 & 67 & 67 \\
\hline & Pearson Correlation & $0,322^{* * *}$ & $0,349^{* * *}$ & $0,735^{* *}$ & 1 & 0,201 \\
\hline \multirow[t]{3}{*}{ Kedisiplinan } & Sig. (2-tailed) & 0,008 & 0,004 & 0 & & 0,102 \\
\hline & $\mathrm{N}$ & 67 & 67 & 67 & 67 & 67 \\
\hline & Pearson Correlation & 0,121 & $0,593^{* *}$ & $0,272^{*}$ & 0,201 & 1 \\
\hline \multirow[t]{2}{*}{ Kepuasan Kerja } & Sig. (2-tailed) & 0,328 & 0 & 0,026 & 0,102 & 0 \\
\hline & $\mathrm{N}$ & 67 & 67 & 67 & 67 & 67 \\
\hline
\end{tabular}

*. Correlation is significant at the 0,05 level (2-tailed).

**. Correlation is significant at the 0,01 level (2-tailed).

a. Hubungan Motivasi (X1) dengan Kinerja (Y)

Variabel motivasi memiliki hubungan dengan kinerja mandor. Hal tersebut dapat dilihat dari hasil analisis korelasi yang diperoleh nilai koefisien korelasi 0,300 dengan nilai signifikansi sebesar 0,014. Apabila membandingkan antara nilai signifikansi dengan 0,05 dan melihat nilai koefisien korelasi yang positif, maka dapat dikatakan $\mathrm{H} 0$ ditolak dan $\mathrm{H} 1$ diterima yang artinya terdapat hubungan yang signifikan dan positif antara variabel motivasi dengan kinerja. Berdasarkan nilai koefisien korelasi yaitu sebesar 0,300 , korelasi atau hubungan antara variabel motivasi dengan kinerja masuk ke rentang 0,200,40 yang artinya tergolong ke dalam kategori berkorelasi rendah merujuk pada teori Guilford (1956). Hasil ini didukung oleh teori dari Kasmir (2016) mengenai kinerja karyawan yang mengatakan bahwa motivasi merupakan salah satu faktor yang dapat memengaruhi kinerja. Selain itu, penelitian Alimah, Sayekti, dan Soelaiman (2016) juga mendapatkan hasil yang sama, yaitu motivasi memiliki hubungan dengan kinerja pemanen di PT Perkebunan Nusantara VII Unit Kebun Kelapa Sawit (UKKS) Rejosari Natar, Lampung Selatan.

\section{b. Hubungan Kemampuan (X2) dengan Kinerja (Y)}

Variabel kemampuan memiliki hubungan dengan variabel kinerja. Hal tersebut dapat dilihat dari hasil analisis korelasi yang diperoleh nilai koefisien korelasi 0,392 dengan nilai signifikansi 0,40 yang merujuk teori Guilford (1956). Pada penelitian Arini, Suryaningsih, dan Djumiarti (2014) mendapatkan hasil yang sama yaitu terdapat sebesar 0,001. Apabila membandingkan antara nilai signifikansi dengan 0,05 dan melihat nilai koefisien korelasi yang positif, maka dapat dikatakan $\mathrm{H} 0$ ditolak dan $\mathrm{H} 1$ diterima yang artinya terdapat hubungan yang signifikan dan positif antara variabel kemampuan dengan kinerja. Berdasarkan nilai koefisien korelasi yaitu sebesar 0,392 , korelasi atau hubungan antara variabel kemampuan dengan kinerja termasuk ke dalam rentang 0,20-0,40 yang artinya tergolong ke dalam kategori berkorelasi rendah merujuk pada teori Guilford (1956). Hasil penelitian ini didukung oleh penelitian dari Setiowati, Widowati, dan Mustam (2015) yang mengatakan bahwa kemampuan kerja memiliki hubungan yang positif dan signifikan dengan kinerja pegawai.

\section{c. Hubungan Kedisiplinan (X3) dengan Kinerja (Y)}

Variabel kedisiplinan memiliki hubungan dengan variabel kinerja. Hal tersebut dapat dilihat dari hasil analisis korelasi yang diperoleh nilai koefisien korelasi 0,322 dengan nilai signifikansi sebesar 0,008. Apabila membandingkan antara nilai signifikansi dengan 0,05 dan melihat nilai koefisien korelasi yang bernilai positif, maka dapat dikatakan $\mathrm{H} 0$ ditolak dan $\mathrm{H} 1$ diterima yang artinya terdapat hubungan yang signifikan dan positif antara variabel kedisiplinan dengan kinerja. Berdasarkan nilai koefisien korelasi yaitu sebesar 0,322 , hubungan antara variabel kedisiplinan dengan kinerja termasuk ke dalam kategori berkorelasi rendah atau berada pada rentang 0,20 hubungan yang positif dan signifikan antara kedisiplinan dengan kinerja karyawan. 


\section{d. Hubungan Kepuasan Kerja (X4) dengan Kinerja (Y)}

Variabel kepuasan kerja tidak memiliki hubungan dengan variabel kinerja. Hal tersebut dapat dilihat dari hasil analisis korelasi yang diperoleh nilai koefisien korelasi 0,121 dengan nilai signifikansi sebesar 0,328. Apabila membandingkan antara nilai signifikansi dengan 0,05 dan melihat nilai koefisien korelasi yang positif, maka dapat dikatakan $\mathrm{H} 0$ diterima dan $\mathrm{H} 1$ ditolak yang artinya tidak terdapat hubungan yang signifikan dan positif antara variabel kepuasan dengan kinerja. Berdasarkan nilai koefisien korelasi yaitu sebesar 0,121 , variabel kepuasan kerja dengan kinerja memiliki korelasi yang sangat rendah dan termasuk ke dalam rentang 0,00 - 0,20 merujuk pada teori Guilford (1956). Hasil penelitian dari Kumala, Burhanuddin, dan Bafadal (2018) mendapatkan hasil yang berbeda, yaitu terdapat hubungan yang positif dan signifikan antara kepuasan kerja dengan kinerja. Akan tetapi pada penelitian Hanifah (2016) menunjukkan hasil yang sama dengan penelitian ini, yaitu variabel kepuasan kerja tidak berpengaruh terhadap kinerja karyawan.

\section{KESIMPULAN}

Variabel motivasi, kedisiplinan, dan kepuasan kerja mandor pada PT Great Giant Pineapple Departemen PG 2 masuk ke dalam tingkat kategori sangat tinggi, sedangkan kemampuan mandor berada pada tingkat kategori tinggi. Variabel motivasi, kemampuan, dan kedisiplinan memiliki hubungan yang signifikan dan positif dengan kinerja mandor, artinya semakin tinggi variabel motivasi, kemampuan, dan kedisiplinan, maka semakin tinggi hasil kinerja mandor. Sedangkan variabel kepuasan kerja mandor tidak memiliki hubungan yang signifikan dengan kinerja mandor.

\section{DAFTAR PUSTAKA}

Alimah FC, Sayekti WD, dan Soelaiman A. 2016. Hubungan gaya kepemimpinan mandor panen dan motivasi kerja pemanen terhadap kinerja pemanen di PT Perkebunan Nusantara VII Unit Kebun Kelapa Sawit (UKKS) Rejosari Natar, Lampung Selatan. Jurnal Ilmu-ilmu Agribisnis (JIIA) Vol. 4 (5): 294-300. http://jurnal.fp.unila.ac.id/index.php/JIA/articl e/view/1504. [24 Oktober 2018].

Arikunto S. 2012. Prosedur Penelitian Suatu
Pendekatan Praktek. Rineka Cipta. Jakarta.

Arini AMD, Suryaningsih M, dan Djumiarti T. 2014. Hubungan kemampuan kerja dan disiplin kerja dengan kinerja pegawai di badan pelayanan perijinan terpadu Kota Semarang. Journal of Public Policy and Management Review (JPPM) Vol. 3 (4): 1-10. https://ejournal3.undip.ac.id/index.php/jppmr/ article/view/6501. [20 Januari 2020].

BKKBN [Badan Kependudukan dan Keluarga Berencana Nasional]. 2010. Norma Keluarga Kecil Bahagia Sejahtera. Badan Kependudukan dan Keluarga Berencana Nasional. Jakarta.

BPS [Badan Pusat Statistik]. 2019. Pertumbuhan Ekonomi Provinsi Lampung. Badan Pusat Statstika. Lampung.

Guilford JP. 1956. Fundamental Statistic in Psychology and Education. 3rd Ed. McGrawHill Book Company, Inc. New York.

Hanifah N. 2016. Pengaruh kepuasan kerja terhadap kinerja karyawan melalui komitmen afektif (studi pada karyawan PT Petrokopindo Cipta Selaras Gresik). Jurnal Ilmu Manajemen Vol. 4 (3): 1-10. https:// jurnalmahasiswa.unesa.ac.id/index.php/jim/art icle/view/16947. [20 November 2019].

Kasmir. 2016. Manajemen Sumber Daya Manusia. Rajagrafindo Persada. Depok.

Kumala IP, Burhanuddin, dan Bafadal I. 2018. Hubungan antara kepuasan kerja, kompetensi, dan kinerja guru. Jurnal Administrasi dan Manajemen Pendidikan Vol. 1 (4): 400-409. http://journal2.um.ac.id/index.php/jamp/ article/download/3353/2769. [20 Januari 2020].

Mangkunegara AP. 2005. Manajemen Sumber Daya Manusia Perusahaan. Remaja Rosdakarya. Bandung.

Mantra IB. 2004. Demografi Umum. Pustaka Pelajar. Yogyakarta.

PT Great Giant Pineapple. 2018. Jumlah Tenaga Kerja dan Hasil Kinerja Mandor. PT GGP. Lampung.

Setiowati H, Widowati N, dan Mustam M. 2015. Hubungan kemampuan dan motivasi dengan kinerja pegawai di Badan Kepegawaian Negara Pusat Jakarta (Studi Kasus di Direktorat Kompensasi Aparatur Sipir Negara). Journal of Public Policy and Management Review (JPPM) Vol. 4 (2): 1-12. https://ejournal3.undip.ac.id/index.php/jppmr/ article/view/8185. [20 Januari 2020]. 